\title{
The Status Quo, Causes, Problems and Countermeasures of China's Film Industry
}

\author{
Dongjin Yang \\ Management School, Jinan University, Guangzhou, China \\ Email: yang.dongjin@163.com
}

Received 8 October 2015; accepted 16 November 2015; published 19 November 2015

Copyright (C) 2015 by author and Scientific Research Publishing Inc.

This work is licensed under the Creative Commons Attribution International License (CC BY). http://creativecommons.org/licenses/by/4.0/

(c) (i) Open Access

\begin{abstract}
Through the collection of the main data (Box Office Revenue, Cinema Screens, Film Viewing, Feature Film Production) of the Chinese film industry in the past 7 years, this paper analyzes the development status and the reason for the rapid development of the industry. Based on data analysis and realistic investigation, this paper points out that Chinese film industry faces some problems, such as lack of connotative development, short industry value chain, and restraints of institutional supply. Correspondingly, this paper puts forward policy and management recommendations.
\end{abstract}

\section{Keywords}

Film Industry, Sustainable Development, Connotative Growth, Industrial Policy

\section{Introduction}

Film is an important vehicle for the spread of a nation's ideology, a means to demonstrate the soft power of a country's culture and the pillar of a country's cultural and creative industry. In 2013, 638 feature films were produced in China, among which 305 were released in the Mainland. While unfortunately, around 200 of the 305 released feature films in the Mainland were on show for only one day due to poor box office performance. Such occurrence is also referred to as "one-day show on the cinema screen". In 2013, box office returns in the Mainland totaled 21.769 billion yuan, among which 9.002 billion yuan came from imports, accounting for 41.35\% of the total returns [1]. Statistics show that Chinese people go to the cinema once every five years, whereas the Americans go to the cinema for 5.7 times every year and South Koreans 2.27 times a year [2].

Over the past decade, the major impetus to the rapid growth of China' film industry comes from the external environment. Thanks to the expansion of factors of production, the strong support of state policy, the huge population base, the urbanization development and the size of China's economy [1] [3]. The endogenous impetus (especially the content and quality) to film industry has had no desirable improvement [4]. Mainstream films, 
which are "filled with dry and stiff preaching", mainly rely on official documents with no respect to the laws of the market. As a result, it is difficult for mainstream films to win the viewers and the market, and achieve the anticipated propagation effects and external benefits in terms of artistic appreciation and ideological education [5]. Under such circumstances, mainstream filmmakers should understand and cater to the viewers' demands rather than immerse in their own fantasies [6]. Commercial films are relatively prosperous compared with mainstream films. However, excessive pursuit of commercial gains has resulted in the "natural phenomenon" of hypercorrection during the transition [7]. The over-emphasis on entertainment has diluted the artistic composition of commercial films and hindered the development of Chinese films.

It is urgent that China' film industry transforms from extensive growth led by policy and investment to connotative and intensive growth so as to secure the healthy and sustainable development of the industry. For the above reasons, this article will focus on three topics of China's film industry: reasons for the rapid development; main problems the industry faces; and countermeasures for sustainable development.

\section{The Status Quo of China's Film Industry}

\subsection{Major Indicators Show Steady Growth}

Major Indicators and Growth Rate of Chinese Film are listed in Table 1. China's film box office revenue topped 10 billion yuan in 2010 and has maintained rapid growth ever since then. In 2013, the box office revenue reached 21.769 billion yuan. During 2007 and 2013, the average annual increase of cinema screens in China amounted to $29.8 \%$. By 2013, the total number of cinema screens nationwide reached 18,195 mainly due to the rapid growth of cinema screens in the second and third tier cities. And the average annual film-viewing trips go up by $31.8 \%$, with 610 million viewing trips in 2013. Low as the annual growth rate of feature film is when compared with other indicators, that figure is still above $10.8 \%$.

\subsection{Demands in the Second and Third-Tier Cities Grow Rapidly}

A large number of modern cinemas have been built or rebuilt in the second and third tier cities where the box office revenue is growing faster than that in the first-tier cities. By 2013, there are over 1500 cinemas in county-level cities with over 5000 cinema screens and 295 cinema lines in rural areas. In the same year, there are 3027 films that have been subscribed by cinema lines in rural areas with an accumulative subscription of 9,111,465 sessions (films subscribed by the government with public release copyright accounts for $62.8 \%$ ). And the film viewing trips equals to 1.5 billion, more than twice the amount of viewing trips to urban cinemas [8]. The growing demand for films in the second and third tier cities, county level towns and rural areas has created new channels for value increase of film products, which also means that films have gone "national wide".

\subsection{Changes in the Structure of China's Film Industry}

During the last few years, private capital has weakened the monopoly of state-owned producers and reduced the industry concentration in film production. The CR4 index of film production has declined from 57\% in 2002 to 27\% in 2010. The market share of China's largest film production company, China Film Group Corporation,

Table 1. Major indicators and growth rate of Chinese film (2007-2013).

\begin{tabular}{ccccccccc}
\hline Year & $\begin{array}{c}\text { Box office revenue } \\
\text { (billion yuan) }\end{array}$ & $\begin{array}{c}\text { Growth rate } \\
\text { (\%) }\end{array}$ & Cinema screens & $\begin{array}{c}\text { Growth rate } \\
(\%)\end{array}$ & $\begin{array}{c}\text { Film viewing } \\
\text { (million) }\end{array}$ & $\begin{array}{c}\text { Growth rate } \\
\text { (\%) }\end{array}$ & $\begin{array}{c}\text { Feature film } \\
\text { production }\end{array}$ & $\begin{array}{c}\text { Growth rate } \\
\text { (\%) }\end{array}$ \\
\hline 2007 & 33.27 & 27.0 & 3527 & 16.2 & 114 & 28.1 & 402 & 21.8 \\
2008 & 43.41 & 30.5 & 4097 & 16.2 & 141 & 23.7 & 406 & 1.0 \\
2009 & 62.06 & 43.0 & 4723 & 15.3 & 200.4 & 42.1 & 456 & 12.3 \\
2010 & 101.72 & 64.0 & 6256 & 32.5 & 286 & 42.7 & 526 & 15.4 \\
2011 & 131.15 & 28.9 & 9286 & 48.4 & 370 & 29.4 & 558 & 6.1 \\
2012 & 170.73 & 30.2 & 13,118 & 41.3 & 470 & 27.0 & 745 & 33.5 \\
2013 & 217.69 & 27.5 & 18,195 & 38.7 & 610 & 29.8 & 638 & -14.4 \\
\hline
\end{tabular}

Data source: Sorted and calculated according to the data: (a) released on the official website (http://www.film.cn/) of State Administration of Radio Film and TV (SARFT); (b) reported by China Film Industry Report 2013 [8]. 
decreased from 32\% in 2001 to $10 \%$ in 2010 [4]. Although there are as many as four to five hundred film production companies in China, only a few companies such as China Film Group Corporation, Huayi Bros. Media Group, Enlight Media, Bona Film Group Limited and Le Vision Pictures have considerable market influence. Each of those companies has relatively equal market share of about $10 \%$. And private enterprises have constituted the backbone of China's film industry in the terminal market. In 2013, 86.3\% of the 80 films with over tens of millions of box office revenue are produced by private enterprises, and $90.6 \%$ of the 32 films with hundreds of millions of box office revenue are produced by private enterprises. Due to the historical residual of administrative monopoly, the CR8 index of the concentration of film distribution companies stays above $80 \%$ since 2007, which indicates a highly oligopolistic market. The CR5 and CR10 cinema line concentration indexes are $34 \%$ and $47 \%$ respectively, which belongs to $\mathrm{V}$ type oligopoly.

\subsection{Great Potential in per Capita Index}

According to the census data, every one million Chinese people have 13.4 cinema screens in 2013 and 7 cinema screens in 2011, which is not promising when compared horizontally with other countries. The data of 2011 has made it clear that the amount of cinema screens for every one million Americans, French, British and Japanese is $137,91,63$ and 26 respectively. And the situation stays the same when it comes to average film viewing. The average film viewing trips of Chinese people are 0.45 in 2013 and 0.27 in 2011, while in the same period that figure for the Americans, French, British, Singaporean and South Korean is 4.6, 2.9, 2.67, 4.2 and 3.1 respectively [4]. It is estimated that there is still a growth potential of 3 trillion yuan in China's annual cultural consumption [9] if it goes in line with the current economic development, suggesting that cultural products, film market in particular, still enjoy huge potential for growth.

\subsection{Evident Progress in Film-Making Technology}

An increasing number of films are produced with 3D, IMAX and CFGS technology. And there have been unprecedented breakthroughs in special effect and post-processing techniques. In 2013, six of the top ten box office earners are high-tech films produced in China, which is close to the United States in terms of the percentage of high-tech films. Moreover, modern multi-screen cinemas have replaced the traditional single-screen cinemas in the terminal market. On one hand, cinemas are better-equipped with an increasing number of digital screens, 3D screens and IMAX screens. In 2012, there are over 100 giant IMAX screens, ranking the second in the world; on the other hand, information technology such as paperless ticket system has been widely applied in cinemas.

\section{Reasons for the Rapid Development of China's Film Industry}

\subsection{China's per Capita GDP Exceeded 5000 US Dollars}

China's per capita GDP was about 4400 US Dollars in 2010. That figure exceeded 5000 US Dollars and reached 5540 US Dollars in the following year, and then about $\$ 6629$ in 2013. Based on the word's economic development, when the per capita GDP of a country or region reaches 5000 US Dollars, the tourism industry will experience explosive growth [10]. The rapid growth of China's film box office revenue and viewing trips since 2007 has proved that fact. The underlying reason is that Chinese people whose material needs have been basically satisfied have turned to products for spiritual enjoyment and entertainment.

\subsection{Superimposed Effect of Policy Support}

A series of documents facilitating the development of cultural industry including Decisions of the Central Committee of the Communist Party of China on Some Major Issues Concerning deepening the Reform of Cultural System and Promoting Vigorous Development and Prosperity of Socialist Culture and Guidance on the Financial Support of the Cultural Industry Promotion and the Development and Prosperity have been enacted by Chinese government. In 2010, the General Office of the State Council issued The Guidance on the Promotion of Film Industry Prosperity and Development, which is the first specific plan for China's film industry issued in the name of the State Council. The Guidance set the target that "the average annual growth of aggregated film economy shall exceed 20\%" and put forward specific requirements for the yield, quality, distribution, sales and production of films. Driven by the central government, local authorities have made greater efforts in developing 
film industry by issuing a series of mandatory targets, offering preferential policies and economic resources, all of which have injected strong impetus into the development of film industry and facilitated a leap forward of the industry.

\subsection{Promotion of Investments}

First, governments at various levels have increased financial investment in addition to strong industrial policy support. Some even become the major investor of films, for instance, Tangshan municipal government invested 60 million yuan in the shooting of Tangshan Earthquake and Tongdao county government sponsored and invested in the shooting of Troop Transfer in Tongdao; second, funds from banks. Major domestic banks have increased involvement in film and television industry. From 2004 to 2012, the publicly disclosed bank loans granted to film and television industry surpassed 1.3 billion yuan [3]; and third, the inflow of cultural industry fund, PE, VC and private capital. The influx of funds have diversified and enriched the financing channels and sources of film industry, resulting in greater investment in the production, distribution and public release of Chinese films.

\section{Main Problems in the Development of China's Film Industry}

\subsection{Serious Waste of Resources, Lack of Connotative Development}

Table 2 provides an insight into the yield and public release of domestic feature film from 2007 to 2013, as well as the ratio between the yield and public release. During the past seven years, the average annual release of feature films in cinemas takes up only $26.3 \%$ of the annual yield. To put it in another way, over two thirds of Chinese feature films are doomed to be in the warehouse and will never find their way into cinemas. The truth is the majority of such films are mainstream films produced by state-owned companies. Furthermore, the "warehouse doomed" films are also resulted from immature investment market, incomplete system and irrational or unhealthy investment objectives of outside investors. Some investments will definitely suffer great losses, while the investors can not stop their investment even if the films are destined to be a failure. As a result, a large quantity of films will never greet the viewers on cinema screens, and a number of film and television bases and industrial parks are merely image projects that have achieved nothing but heavy losses.

Despite that the box office revenue, the amount of cinema screens and viewing trips and the production of feature films have maintain an annual growth of over $10 \%$, the main contributors of the growth are the macroeconomic environment, industrial policy and vigorous promotion of various types of funds. As is shown in Table 2, data analysis indicates that the connotative development of Chinese films is not promising. Above all, the ratio between publicly released films and the yield has been low; secondly, overseas earnings of domestic feature films have been declining after the year 2010 when that figure hit 3.517 billion yuan; and thirdly, the domestic market share of Chinese films has been hovering around 55\%, making it obvious that foreign films especially American films have taken a large proportion of profits from China's market. In addition, the content is of essential importance for cultural products like films. Unfortunately, there has been no breakthrough in Chinese films concerning the genre and subject matter. In consequence, Chinese films can not assume the responsibility of moral education and cultural export.

Table 2. Major indicators of domestic feature films.

\begin{tabular}{cccccc}
\hline Year & Production & Public release & Released /production (\%) & Overseas earnings (billion yuan) & Domestic market share (\%) \\
\hline 2007 & 402 & 74 & 18.4 & 2.02 & 75.0 \\
2008 & 406 & 80 & 19.7 & 2.34 & 60.8 \\
2009 & 456 & 88 & 19.3 & 2.77 & 56.6 \\
2010 & 526 & 91 & 17.3 & 3.517 & 57.0 \\
2011 & 558 & 154 & 27.6 & 2.046 & 53.6 \\
2012 & 745 & 231 & 31.0 & 1.063 & 48.5 \\
2013 & 638 & 326 & 51.1 & 1.414 & 54.3 \\
\hline
\end{tabular}

Data source: Sorted and calculated according to the data: (a) reported by The Development of China's Film Industry: Traps and Causes [3]; (b) reported by The Analysis Report of China Film Enterprise in 2013 [11]; (c) released on the official website (http://www.film.cn/) of State Administration of Radio Film and TV (SARFT). 


\subsection{Exploitation of Film Derivatives Remains in Primary Stage}

Film derivatives refer to all products that can increase the downstream value of film industry other than the release on cinema screens, including audio-visual products, books, toys, video games, souvenirs, costumes and theme parks, etc. Film derivatives continue to generate revenue for the producers over time long after the public release of films. Derivatives of American films have become an important source of income other than box office revenue, for example, the total box office revenue of Star Wars Trilogy is 1.8 billion US Dollars, while the revenue from derivatives is more than 4.5 billion US Dollars [11]. The main returns of Chinese films come from pre-rolls, implant advertising and box office revenue. And the category of Chinese film derivatives is limited to toys and souvenirs, etc. Talents in the film industry chain are quite different from those in manufacturing industry. Films talents refer to those with proficiency in diversified areas and a border range of disciplines, including literature, play-writing, directing, acting, photographing, art, recording, planning, production, post-production, distribution, public release and marketing, etc. With the employment of high technology and the horizontal and vertical expansion of film industry chain, the requirements for the professionalism and comprehensive capability of talents are getting much higher. With the skyrocketing growth of film industry and economy aggregate of film industry in recent years, the existing film professionals, interdisciplinary talents in particular, can not bridge the huge demands. The shortage of talents results in excessive outsourcing of film production, which has jeopardized the artistic contriving, production and profit margin of films.

\subsection{Restraints of Institutional Supply}

Government authorities such as the Ministry of Culture, the State Administration of Radio Film and Television (SARFT) and Press and Publication Bureau are responsible for routine vertical management. Meanwhile, there is a four-level horizontal management structure from the central to local government. Such fragmentation has resulted in excessive business procedures and huge difficulties in resource integration. As to film distribution system, China Film Distribution and Exhibition Corporation, which is attached to the Ministry of Radio, Film and Television, has to play their role as a corporation in the coordination of film distribution across China, and meanwhile assume their duties in the administration of film distribution across the nation. The integration of government administration with enterprise management has affected the efficiency and prestige of government administration.

Currently, the greatest restrict on the development of China's film industry is Film Censorship. The criteria of Chinese Film Censorship are based on Regulations on Administration of Films enacted by the State Council in December 2011. But the situation is Chinese film must face close-linked and strict censorship. The reviewers of various administration authorities will follow strictly the criteria for censorship; while the producers may neglect the realistic criticism and artistic pursuit of films just to pass the censorship and secure their funds. Due to the restraints of the system, the subject matters of Chinese films are restricted to dull and monotonous historical story, kungfu and Anti-Japanese War. Moreover, such restraints have resulted in the waste of resources as a certain number of mainstream films are not popular among the viewers while other films with fine artistic taste are not well-received in domestic market.

\subsection{Incomplete Financing System}

Film industry is essentially a capital-intensive and high-risk business with high returns. The fund of Chinese film industry mainly comes from equity capital, financing (bank loans, public financing, venture capital and private equity fund) and government finance support. The investors include state-owned film production companies and new type production companies with diversified capital composition. At this stage, the policies and regulations on investment and financing of film industry remain uncertain though capital investment has been active in the industry for years. And the risk of investment in film industry has also accelerated, which is evident in that a greater number of private television and film companies go into crisis for capital chain rupture in recent years and a significant increase in lawsuits due to incomplete financing mechanism.

\section{Countermeasures for Sustainable Development of China's Film Industry}

\subsection{Improve the Film Attractiveness, Complete the Third-Tier Market Mechanism}

Content is of primary importance for films despite that cinemas and projection equipment are equally important. 
The real attraction for film viewers are the story, thoughts, feelings and emotions contained in the films and the resonance and spiritual sublimation they can obtain in the film viewing process. What determines the competitiveness of film industry are the content and connotative significance of film products. The majority of mainstream films in China are not viewer-oriented with no real sentiments that can touch upon the viewers. Similarly, due to film censorship and the artistic pursuit of producers, the subject of commercial films are limited to ancient costume, Kung Fu, wars, thrill, romance and entertainment, which can not reflect the humanity, the society, the reality as well as the history. Chinese films fail to meet the market demand in term of both themes and emotional resonance. There are three suggestions for such problems. First of all, government authorities should make a difference by refraining from suppressing the development of film industry for their own interests. It is their responsibility to respect the law of artistic creation and give more freedom to the expression of film content; secondly, it is necessary to speed up the legislation of Motion Picture Act as stated in the previous paragraphs, which makes it possible to administrate film industry by law rather than the officials' own will; and lastly, it is important to strengthen the support for microfilms. Microfilm is the experimental field for the diversity and realism of films and the cradle of film creation, production and talent nurturing. Improving the attractiveness of domestic films brings about social significance in terms of the dissemination of culture and ideas except from economic significance. On one hand, the ratio between the yield and public release of films can be raised to avoid the waste of resources; on the other hand, the market share of domestic feature films can be increased to avoid "the shortage of film products under huge market demand" and the overwhelming advantage of foreign films in China's market that is cultivated with so much effort through the "marketization before industrialization" model.

In recent years, the government has offered much support for the construction of cinemas lines in the second-tier film market ${ }^{1}$. And the third-tier film market has been included in public cultural services programs in accordance with the "2131" project. The cost of film release in the third-tier market is borne by the government. SARFT spends 5 million yuan annually to purchase the rural digital copyright of over 60 feature films and 30 popular science films, all of which are provided to cinemas lines in rural areas through online platforms [12]. It is obvious that the sharp increase in the box office revenue of the second and third-tier market is mainly driven by policy support. Government policies are beneficial for the gradual cultivation of film viewing habits of urban and rural residents; however, policies alone are not enough for the sustainable development of the rural film market. Therefore, the completion of the third-tier market mechanism becomes imperative. The government will offer guidance rather than dominance in the development of the second and third-tier market. On one hand, the government shall help cinemas to break down regional and administrative barriers, guide them to develop and operate the third-tier market independently and jointly; on the other hand, the government shall provide policy support for the construction of cinemas in the second and third-tier market to expand the overall size of China's film market.

\subsection{Expand the Industrial Value Chain, Encourage Cross-Industry Mergers}

Companies that attach high importance to film derivatives can reap profits repeatedly in different domains by taking advantage of their products, services, images, trademarks and brands. In this way, the same product, service, image, trademark and brand have been endowed with diversified applications and multiplied profits. The Walt Disney Company, the one that has packaged Mickey Mouse, Donald Duck, Aladdin, The Lion King and other cartoon characters in different ways, can serve as a typical example. The company has gained enormous profits in various domains such as films, theme parks, tourism, catering, franchise stores, clothing, books and games. So far, the revenue from Chinese film derivatives accounts for less than 30\% of the total revenue [10]. Chinese film enterprises are sparing no effort to increase the revenue from film derivatives. For instance, the Pleasant Goat and Big Big Wolf-Bullish produced by Creative Power Entertaining has garnered more than 100 million US dollars of box office revenue, and has also gained a fortune from film derivatives (children's clothing, books, audio-video products, bags, value-added services, ice cream, stuffed toys and plastic toys, etc.). While, the truth is that more efforts must be taken by China's film industry in this respect compared with American film industry. It is necessary to further explore and nurture market segments and satisfy the demands of consumers so as to maximize the influence of films and the value of the copyright, thus expanding the value

${ }^{1}$ The second-tier film market refers to film release activities other than those in mainstream cinemas and cinemas above county level, including regional mobile film release activities in cinemas that have joined the cinema lines, movie theater, clubs and government institutions enterprises and public institutes, schools, communities. The third-tier film market refers to the rural market. 
chain of film industry both horizontally and vertically.

Currently, almost all the world-class film enterprises such as Time Warner Inc, The Walt Disney Company and Twentieth Century-Fox Film Corporation are part of integrated media enterprises. This diversified conglomerate model enjoys three advantages. Above all, this model can enhance the enterprises' ability to withstand investment risks and ensure the stable cash flow of film business; second, this model enables the establishment of a complex industrial chain which can gain multiplied profits from film derivatives; and third, this model has raised the threshold for film industry and reduced cut-throat competition and waste of resources. At the present, Chinese film enterprises are short of such diversified business and are tormented by fragmentation and degradation of industrial value chain. Therefore, the government should encourage and promote the merger and acquisition of Chinese film enterprises, gradually eliminate the barriers between industries and integrate film industry with radio and television, press and publications, newspapers and magazines, tourism, culture, the Internet, new media and manufacturing. This will bring into full play the role of film industry in achieving economy of scope and scale and strengthen the international competitiveness of Chinese films; meanwhile, the government should support small enterprises with specialized, industrialized and differential business to take in the outsourcing business of large enterprises. The collaboration can manifest the comparative advantages of both small and large film enterprises, enhance the production capacity of Chinese films and promote the development of China's film industry.

\subsection{Establish Film Rating System and Enact Motion Picture Act}

With the evolvement of people's thinking, film censorship can no long satisfy the viewers' demand for content diversification. Consequently, film censorship has been abandoned and replaced by film rating system in developed countries. The establishment of film rating system is based on a complete set of legal system and legislation for film rating. Though the existing policies and regulations have standardized the administration of China's film industry, they are not authoritative and powerful enough compared with laws enacted by the state. In this case, film industry is to a large extent administrated under the officials' own will. It is urgent that legislative authorities speed up the legislative process and enactment of Motion Picture Act with the least possible delay in order to provide legal protection for the administration of China' film industry.

\subsection{Improve the Financing Operating Mechanism of Film Industry}

Firstly, it is necessary to develop a scientific investment and financing evaluation system, explore new financing methods, optimize the financing structure and establish a complete evaluation system and transaction platform; secondly, it is important to set up guarantee and supervision institutions, particularly bonding companies to guarantee the completion of film production. The existing bonding companies should be encouraged to provide special services to film financing and the third party supervision institutions should be urged to make systematic analysis of film projects from the proposal stage; thirdly, it is helpful to create a film industry database for the scientific decision-making of film production, which can reduce the operation risks arising from the investors' perceptual decisions rather scientific analysis due to the lack of highly authentic statistics for reference; fourthly, it is urgent that a sound producer mechanism should be established. The current producer mechanism in China has inherited the contract responsibility system in agricultural sector. Many directors are forced to be contractors, which leads to abnormal industrial patterns. Actually, it is better to learn from the American film production system which gives full play to the role of consulting firms, service sector, insurance industry, law firms, finance corporations and clearly defines the rights and obligations of all parties involved to ensure the safety of funds and the quality of films; and finally, it is essential that a schedule coordination mechanism should be established to promote the differential operation of cinemas, which helps to reduce cut-throat competition and unnecessary conflicts and improve the quality of film distribution.

\section{Conclusion}

Driven by external factors such as policies and investment, China's film industry has experienced rapid development in recent years; however the content and quality of essential factors of production within the industry have witnessed no obvious improvement. To achieve the transformation from extensive growth to connotative growth, it is necessary to accelerate legislation for film industry, complete the industrial value chain and operat- 
ing mechanism, encourage cross-industry mergers of enterprises, enhance the attractiveness of films and build up a three-tier market mechanism.

\section{Foundation}

The Humanities and Social Science Foundation of the Ministry of Education "Policy Support, Governmental Shadow and the Lack of Autonomous Brands" (12YJA630167).

\section{References}

[1] Li, Y.B. (2014) The Contrast between Market Data and Viewer Evaluation of Chinese Films in 2013 [EB/OL]. http://news.kunming.cn/entertainment/content/2014-01/10/content_3478686.htm

[2] Wu, X.D. (2014) Why Films Become Luxurious Consumption? [EB/OL]. http://news.xinhuanet.com/observation/2010-08/24/c_12477727_3.htm

[3] He, Q. (2013) The Development of China’s Film Industry: Traps and Causes. Film Art, 4, 52-59.

[4] Jin, X.T. (2013) A Study on the Optimization of China’s Film Industry Chain-From the International and Comparative Perspective. Modern Communication, 4, 96-100.

[5] Chen, X.H. (2010) An Outline of China's Historical Development in Academic Film Studies. Journal of Shanghai University (JCR Social Science Edition), 4, 37-59.

[6] Rao, S.G. (2009) The Construction of Chinese Mainstream Films during the 30 Year's Reform and Opening up. Literature \& Art Studies, 1, 76-84.

[7] Yin, H. (2010) Review on Chinese Film Art in 2009. Contemporary Cinema, 3, 4-11.

[8] Yin, H. and Yin, Y.Y. (2014) China Film Industry Report 2013. Film Art, 2, 5-18.

[9] Zhu, X.Y., Li, S.M. and Zhang, Q. (2013) The Composition and Expansion of the Cultural Industry Value Chain. Economic Review, 7, 74-77.

[10] Wang, C.J., Pan, Y. and Liu, F. (2014) Development of American Film Industry and Its Implications for Emerging Chinese Cultural Industry. China Soft Science, 5, 49-57.

[11] Sun, H., Liu, H.W. and Song, J.W. (2014) The Analysis Report of China Film Enterprise in 2013. Contemporary Cinema, 3, 21-28.

[12] Nie, Z. (2013) The Operational Strategies of the Film Market in China. On Economic Problems, 1, 97-101. 